\title{
Systematic Literature Review (SLR) sebagai Alternatif Penelitian pada Masa Pandemi Covid-19
}

\author{
Wulan Anggraeni, Adhi Susano, Indra Suyahya \\ Universitas Indraprasta PGRI \\ *wulananggraeni41183@gmail.com
}

\begin{abstract}
Abstrak
Kegiatan pelatihan SLR merupakan salah satu kegiatan pengabdian masyarakat (abdimas) yang dilakukan oleh dosen di lingkup Universitas Indraprasta PGRI. Kegiatan abdimas ini bertujuan agar peserta dapat menguasai tahapan-tahapan yang dilakukan pada SLR serta tetap produktif melakukan penelitian pada masa pandemi Covid19. Selain itu juga dapat menemukan state of the art pada penelitian yang dilakukan. Materi yang diberikan adalah pengenalan SLR dan tahapan melalukan review artikel secara sistematis. Hasil dari pelaksanaan abdimas ini yaitu peserta tetap aktif melakukan penelitian pada masa pandemi Covid-19 dengan metode SLR. Terbukti peserta mendapatkan manfaat dari Pelaksanaan kegiatan dengan nilai penyajian materi sebesar 81,5\% menyatakan sangat baik dan $18,5 \%$ menyatakan baik. Pemilihan tema juga dinilai sangat baik dengan nilai $85 \%$ karena relevansi materi dengan kebutuhan peneliti di masa pandemi Covid-19.
\end{abstract}

Kata Kunci: SLR, penelitian, state of the art

\section{Systematic Literature Review as an Alternative for Research during The Covid-19 Pandemic}

\begin{abstract}
The SLR training activity is one of the community service activities (abdimas) carried out by lecturers at the Indraprasta University PGRI. This community service activity aims to enable participants to master the stages carried out in the SLR and remain productive in conducting research during the Covid-19 pandemic. In addition, it can also find the state of the art in the research conducted. The material provided is the introduction of SLR and the stages of systematically reviewing articles. The result of the implementation of this service is that participants remain active in conducting research during the Covid-19 pandemic using the SLR method. It was proven that the participants benefited from the implementation of the activity with a material presentation value of $81.5 \%$ stating it was very good and $18.5 \%$ said it was good. The choice of theme was also considered very good with a score of $85 \%$ because of the relevance of the material to the needs of researchers during the Covid-19 pandemic.
\end{abstract}

Keywords: SLR, research, state of the art

\section{PENDAHULUAN}

Wabah virus Covid-19 yang terjadi di Indonesia saat ini, mengakibatkan masyarakat harus menerapkan pembatasan interaksi sosial dalam semua kegiatan, termasuk kegiatan dalam sektor pendidikan. Berdasarkan surat edaran kementerian pendidikan riset, teknologi nomor 1 tahun 2020, menghimbau bahwa selama masa pandemi Covid-19, Pimpinan PTN dan LL Dikti menyampaikan kepada civitas akademik untuk menjaga perilaku hidup bersih dan sehat (PHBS), serta melakukan social distancing selama melaksanakan pengajaran, penelitian dan pengabdian kepada masyarakat. Pada bidang penelitian, para dosen, peneliti dan mahasiswa harus dapat merubah arah penelitian dengan tidak melibatkan kontak langsung antara peneliti dengan subyek yang diteliti. Untuk itu perlu suatu alternatif penelitian. Salah satu alternatif yang dapat dipergunakan adalah systematic literature review (SLR). 
Vol. 2, No. 2, July, 2021, pp. $137-141$

e-ISSN: 2722-2004

\section{Systematic}

Literature

Review as an

Alternative for

Research

during The

Covid-19

Pandemic

W. Anggraeni,

Adhi Susano,

Indra Suyahya

SLR adalah suatu metode penelitian untuk melakukan identifikasi, evaluasi dan interpretasi terhadap semua hasil penelitian yang relevan terkait pertanyaan penelitian, topik, atau fenomena yang menjadi perhatian (Kitchenham, 2004). Langkah yang dilakukan dalam SLR menurut Perry \& Hammodn (2002) adalah:

1. Mengidentifikasi pertanyaan penelitian

2. Mengembangkan protokol penelitian meta analisis.

3. Menetapkan lokasi data base hasil penelitian

4. Menyeleksi hasil penelitian relevan

5. Memilih hasil penelitian yang sesuai dengan topik dan berkualitas

6. Mengekstraksi data dari studi individual

7. Menyintesis hasil penelitian

8. Menyajikan hasil penelitian dalam laporan penelitian hasil meta analisis.

Untuk dapat menerapkan SLR sesuai tahapan yang ada, maka perlu adanya literasi SLR di kalangan para dosen serta mahasiswa S-1, S-2, dan S-3 yang sedang menyelesaikan karya ilmiahnya, selain itu juga kegiatan ini dapat membantu para reviewer jurnal agar dapat me-review secara sistematis. Berlandaskan hal tersebut maka diselenggarakan kegiatan kuliah umum dengan tema Systematic Literature Review sebagai Alternatif Penelitian pada Masa Pandemi Covid-19.

\section{METODE PELAKSANAAN}

Kegiatan pelatihan SLR dilaksanakan pada 29 November 2020 melalui Zoom dan live streaming YouTube. Adapun jumlah peserta sebanyak 570 orang yang berasal dari kalangan dosen, guru, serta mahasiswa/i dari wilayah Jakarta, Bogor, Tangerang, Depok, Bekasi, Sukabumi, Bandung, Cirebon, Palembang dan Kalimantan.

Tim abdimas menggunakan metode pengembangan ADDIE Model. ADDIE memiliki tahapan yang sistematis, dan lebih rasional yaitu terdiri dari lima tahap: analysis, design, development, implementation, evaluation (Samala dalam oktiviandani et al., 2020). Selanjutnya tim melakukan penilaian terhadap kegiatan mulai pendaftaran peserta dilakukan melalui link yang telah disiapkan, peserta dapat memilih Zoom atau live streaming YouTube. Kegiatan berlangsung mulai pukul 07.30 WIB sampai dengan 12.10 WIB, di akhir acara peserta mengisi absensi dan penilaian terhadap kegiatan yang dilakukan. Adapun angket yang digunakan untuk menilai acara tersebut disajikan pada Tabel 1.

Tabel 1. Angket Penilaian kegiatan SLR

\begin{tabular}{|c|c|c|c|c|c|c|}
\hline No. & Pertanyaan & SB & B & $\mathrm{C}$ & K & $\mathbf{B R}$ \\
\hline 1 & Pemilihan tema kegiatan & & & & & \\
\hline 2. & $\begin{array}{l}\text { Ketepatan waktu dalam } \\
\text { memulai acara }\end{array}$ & & & & & \\
\hline 3. & $\begin{array}{l}\text { Kemampuan panitia } \\
\text { berinteraksi dengan peserta }\end{array}$ & & & & & \\
\hline 4. & Pemilihan nara sumber & & & & & \\
\hline 5. & $\begin{array}{l}\text { Penguasaan materi nara } \\
\text { sumber }\end{array}$ & & & & & \\
\hline 6. & $\begin{array}{l}\text { Penyajian materi oleh nara } \\
\text { sumber }\end{array}$ & & & & & \\
\hline
\end{tabular}

Angket penilaian yang disebar kepada peserta pada Tabel 1, terdiri atas 6 butir pertanyaan, yang terdiri dari 3 penilaian terhadap panitia dan 3 penilaian nara 
sumber. Pilihan terdiri atas 4 kategori yaitu sangat baik (SB), baik (B), cukup (C), kurang (K), buruk (BR).

\section{HASIL DAN PEMBAHASAN}

Acara diselenggarakan pada 29 November 2020 telah berjalan lancar. Diawali dengan beberapa persiapan sebelum tanggal pelaksanaan. Adapun persiapan yang dilaksanakan adalah menyiapkan tema yang sesuai dengan keadaan penelitian pada masa pandemi, penyusunan proposal, izin melakukan kuliah umum kepada prodi, LPPM dan Rektorat, serta persiapan lainnya.

Total jumlah peserta yang mengikuti adalah 570 peserta yang berasal dari dosen, guru, dan mahasiswa. Adapun peserta berasal dari Jabodetabek, Sukabumi, Bandung, Majalengka, Cirebon, Palembang, dan Kalimantan. Pada saat kegiatan, peserta harus mengikuti tata tertib yang sudah di sosialisasikan panitia. Kegiatan Kuliah dimulai pada pukul 08.00 dan berakhir pada pukul 12.10. Kegiatan di awali dengan para peserta memasuki ruang virtual Zoom sesuai dengan aturan yang telah disosialisasikan oleh panitia. Dilanjutkan dengan laporan pertanggung jawaban ketua panitia dan sambutan rektor Universitas Indraprasta PGRI. Setelah acara resmi dibuka oleh Rektor, selanjutnya pembacaan doa. Acara inti dibawakan oleh Romi Satria Wahono, Ph.D dan dipandu oleh Dr. Hasbullah sebagai moderator. Bukti kegiatan SLR disajikan pada Gambar 1.

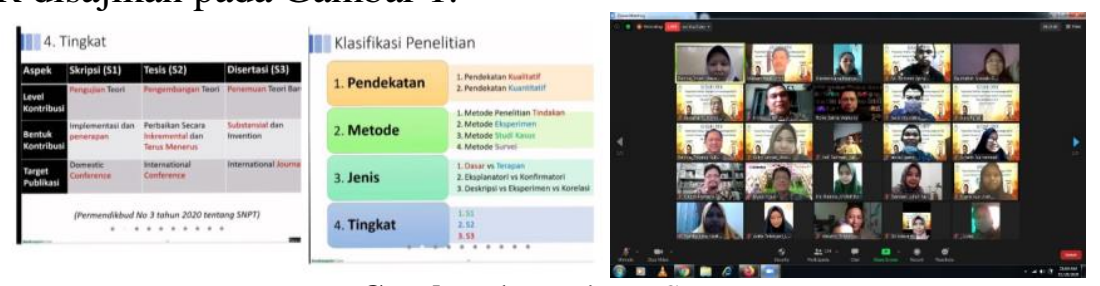

Gambar 1. Kegiatan SLR

Pemaparan materi diawali dengan definisi penelitian, yaitu suatu proses untuk mengeksplor sesuatu yang belum diketahui, mempelajari hal baru, membangun pengetahuan baru tentang suatu hal yang belum dipahami (Berndtsson et al, 2008). Proses investigasi terhadap suatu masalah yang dilakukan secara berulang-ulang dan sistematis, dengan tujuan menemukan atau merevisi teori, metode fakta dan aplikasi dapat memberikan kontribusi terhadap penelitian (Dawson, 2009). Selanjutnya menjelaskan beberapa penelitian terapan yakni penerapan C4.5 dalam memprediksi kelulusan mahasiswa menggunakan teori Gain (Kullback \& Leibler, 1951).

Selanjutnya, pembahasan tentang penggunaan SLR dalam berbagai bidang ilmu pengetahuan yaitu, medicine, computing, social, dan business management. Pembahasan yang dilakukan juga terkait dengan tahapan yang dilakukan dalam SLR yakni planning, conducting, dan reporting. Setiap tahapan dijelaskan dengan detail. Kemudian acara dilanjutkan dengan sesi diskusi. Semua pertanyaan yang diajukan oleh peserta dapat dijawab dengan baik dan memuaskan.

Pada akhir acara peserta memperoleh sertifikat sebagai bukti telah mengikuti kuliah umum SLR. Peserta yang memperoleh sertifikat adalah peserta yang mengisi daftar hadir melalui link yang sudah digunakan. Untuk peserta yang mengikuti live streaming youtube harus memberikan bukti screen shoot keikutsertaan. Penyerahan sertifikat melalui alamat email masing-masing.

Mendukung penelitian sebelumnya bahwa Systematic Literature Review dapat membantu peneliti mendapatkan kesimpulan dari berbagai sumber (Syelitiar \& 
Vol. 2, No. 2, July, 2021, pp. $137-141$

e-ISSN: 2722-2004

\section{Systematic}

Literature

Review as an

Alternative for

Research

during The

Covid-19

Pandemic

W. Anggraeni,

Adhi Susano,

Indra Suyahya

Putra, 2021). Hal serupa juga dialami oleh peneliti lain, dengan Systematic Literature Review peneliti dapat menyimpulkan kelebihan suatu instrumen pembelajaran online dapat meningkatkan efektivitas belajar (Putra \& Afrilia, 2020). Pelaksanaan pengabdian masyarakat ini telah memberikan manfaat setidaknya pada lebih dari 570 peserta berikut merupakan hasil evaluasi pengabdian kepada masyarakat.

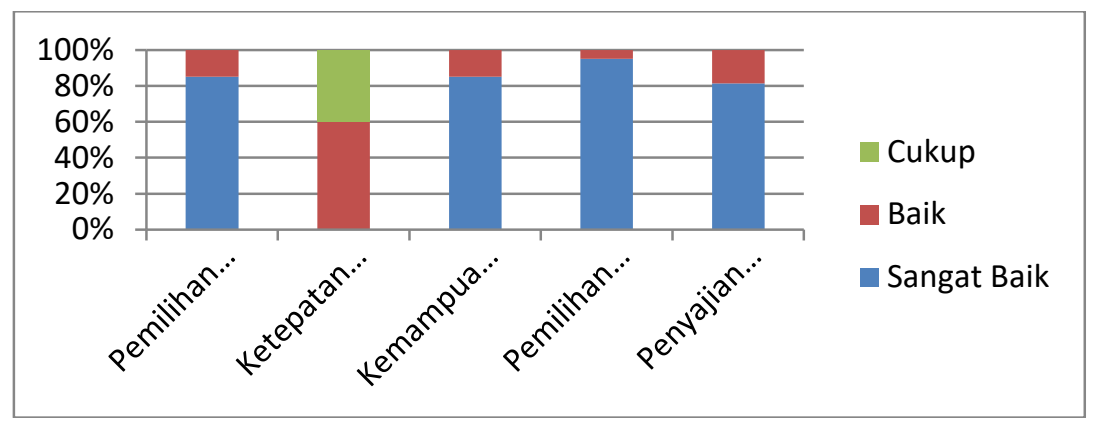

Untuk mengukur hasil keberhasilan acara, tim abdimas melakukan survei dengan angket penilaian sebagaimana yang dijelaskan di atas. Pemilihan tema kegiatan dinilai sangat baik, didasarkan pada pernyataan peserta yang mengisi sangat baik sejumlah $85 \%$ dan baik $15 \%$. Hasil survei ketepatan waktu dalam memulai acara, $60 \%$ peserta menyatakan baik dan $40 \%$ menyatakan cukup. Hasil survei penilaian kemampuan panitia berinteraksi dengan peserta $85 \%$ peserta menyatakan sangat baik dan 15\% menyatakan baik. Sebanyak $95 \%$ menyatakan pemilihan narasumber sangat baik, dan 5\% menyatakan baik. penguasaan materi dinilai sangat baik, dikarenakan $95 \%$ peserta menyatakan sangat baik dan $5 \%$ menyatakan baik. Penyajian materi oleh nara sumber dinilai sangat baik, hal ini diperoleh dari hasil angket, sebanyak 81,5\% menyatakan sangat baik dan 18,5\% menyatakan baik. Dari keenam butir angket yang diisi oleh peserta, dapat dinyatakan bahwa kegiatan SLR data dikatakan sangat baik.

\section{SIMPULAN}

Kegiatan SLR telah terselenggara dengan baik, namun ada beberapa evaluasi yang perlu dilakukan yakni Persiapan yang dilakukan untuk tergolong singkat dalam kurun waktu dua bulan, walaupun demikian persiapan yang dilakukan oleh panitia pada setiap seksi berjalan dengan baik dan lancar, hal ini dapat dilihat dari tanggapan peserta yang menyatakan kegiatan SLR pada kategori sangat baik dan baik.

\section{DAFTAR PUSTAKA}

Berndtsson, M., Hanson, J., \& Olsson, B. (2008). Thesis Projects: a Guide for Students in Computer Science and information System (2nd ed.). London: Springer Verlag.

Dawson, C. W. (2009). Projects in Computing and Information Systems A Student's Guide (2nd ed.). Pearson Education Limited.

Kitchenham, B. (2004). Procedures for Performing Systematic Reviews. Eversleigh: Keele University

Kullback, S., \& Leibler, R.A. (1951). On Information and Sufficiency. The 
analysis of Mathematical Statistics. 22, 79-86.

Perry, A. \& Hammond, N. (2002). Systematic Review: The Experience of a PhD Student. Psychology Learning and Teaching, 2(1), 32-35

Putra, A., \& Afrilia, K. (2020). Systematic Literature Review : Penggunaan Kahoot Pada Pembelajaran Matematika. Jurnal Ilmiah Pendidikan Matematika Al Qalasadi, 4(2), 110-122. https://doi.org/10.32505/qalasadi.v4i2.2127

Robbani, H., Rosadi, N., \& Nurfitria, O. (2020). Pembuatan Ruang Belajar Virtual di Pusat Kegiatan Belajar Masyarakat Smart Bangun Negeri Creating a Learning Management System at the Smart Bangun Negeri Community Learning Activity Center Creating a Learning Management System at the Smart Bangun Negeri $C$.

Syelitiar, F., \& Putra, A. (2021). Systematic Literatur Review: Kemandirian Belajar Siswa Pada Pembelajaran Daring. Sepren, 2(2), 23-31. https://doi.org/10.36655/sepren.v2i2.490

Suyanto. (2007). Makalah disampaikan dalam seminar KTI untuk guru di DIY (11 Januari 2009).

Suyanto. (2003). “Teknik Penulisan Artikel Ilmiah”. Makalah disampaikan dalam Lokakarya Penulisan Jurnal Penelitian Humaniora di Lembaga Penelitian Universitas Negeri Yogyakarta, 23 Oktober 2003. 